great corals, huge siliceous sponges, and what not more-first-fruits of the noble harvest to be gathered from the "Depths of the Sea."

In some things, and again it is no wonder, $\mathrm{Mr}$. Buchanan prefers the old times to the new. He tells us of the cool comfort of an old wooden ship, its perfect fitness for the work of exploration, and how we have no ships nowadays like the Challenger. We are half-tempted to agree with him. He commends, even with enthusiasm, the oldfashioned hempen dredge-rope and sounding-line, and assures us that "wire is the very emblem of treachery." In later years, when wire had come into use, he says: "I never attached a thermometer to the wire without feeling that I was guilty of a form of cruelty-cruelty to instruments." This is a much harder saying-to those of us who have used nothing else; let us hope that it is the wire which has altered, and not the men.

It need scarcely be said that this book is well worth reading. It has many pages to interest even the man in the street, and has both an historical interest and something more besides for the present-day student of oceanography. In these seven-and-forty years methods have been refined, new theories and concepts formed; but we do not forget that birthday party on board the Challenger, nor Mr. J. Y. Buchanan, who is the last of the godfathers.

D'Arcy' W. Thompson.

\section{INDUSTRIAL PSYCHOLOGY.}

Lectures on Industrial Psychology. By Bernard Muscio. Second edition, revised. (Efficiency Books.) Pp. iv +300 . (London: George Routledge and Sons, Ltd.; New York: E. P. Dutton and Co., 1920.) Price $6 s .6 d$. net.

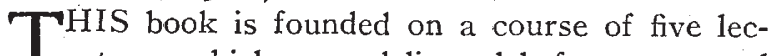
1 tures which were delivered before a general audience at Sydney University, but they must have been considerably expanded when put into book form. The author does not lay claim to have made any first-hand investigations on the problems with which he deals, but the book is very far from being a mere compilation. It shows throughout a deep insight into the principles of industrial psychology, and is especially lucid on the much-debated question of scientific management.

Mr. Muscio takes in turn the various objections to this system raised by the workers themselves, and with great ingenuity tracks down the true inwardness of these objections, and discusses the manner in which they may be overcome. He maintains that the main fact to be insisted on is that NO. 2626 , VOL. IO4] the new methods prevent waste of human energy, and render it possible to obtain a given output from a much smaller expenditure of human energy than that hitherto found necessary. Labour's objection that the general introduction of scientific management would cause widespread unemployment applies equally to every improvement introduced into industry in the past. The difficulty can be largely overcome by installing the improvements gradually and absorbing the surplus workers by the simultaneous introduction of other forms of labour.

Again, Labour maintains that scientific management leads to undue speeding up. There is much truth in this assertion, but the difficulty can be overcome by the introduction of longer intervals of rest and by shortening the working day. Other objections to the system could be avoided by arranging for an adequate system of industrial education. The employer and employee must cooperate in the introduction of a scheme whereby ro time study of an operation shall be made, and no bonus system adopted, without the consent of the worker.

A very interesting and important field of industrial psychology centres around vocational selection. This subject is discussed at length by the author, and concrete instances of the methods as applied to the selection of telephone girls and electric-street-car drivers are described in detail. Industrial fatigue is treated rather briefly, and is the least satisfactory part of the book, as the information adduced is largely out of date. That concerning industrial accidents is fragmentary and misleading, and no reference is made to the "safety first" campaign, and to the effects of suggestion on the avoidance of accidents. The lectures were apparently written in 1916, and the author has endeavoured to bring them up to date in this revised edition by the somewhat irritating and unsatisfactory method of appending footnotes.

H. M. V.

\section{CRIMINOLOGY AND NERVOUSNESS.}

(I) Criminology. By Dr. Maurice Parmelee. Pp. xiii +522 . (New York: The Macmillan Co.; London: Macmillan and Co., Ltd., I9I8.) Price Ios. $6 d$. net.

(2) The Mastery of Nervousness based upon SelfRe-education. By Dr. Robert S. Carroll. Third revised edition. Pp. 348. (New York: The Macmillan Co. ; London: Macmillan and Co., Ltd., I918.) Price Ios. $6 d$, net:

(I) R. PARMELEE has written a very readable book on the various aspects of crime and criminals. He has disclosed nothing that is 